\title{
Assessment of the Trend of Secondary School Students' Academic Performance in the Sciences, Mathemetics and English: Implications for the Attainment of the Millenium Development Goals in Nigeria
}

\author{
Dr. John Sakiyo \\ Science Education Department, \\ Modibbo Adama University of Technology, Yola \\ Dr. K. M. Badau \\ Science Education Department, \\ Modibbo Adama University of Technology, Yola
}

\begin{abstract}
Students' academic performance in the sciences is crucial for national development and the attainment of the Millennium Development Goals. With a year to the end of the MDGs, this study assessed the trend of students' academic performances in Biology, Chemistry, Physics, Mathematics and English in West African Senior School Certificate Examination (WASSCE) from 2008 - 2012. The results of the entire students who sat for this examination in Nigeria in the 5 subjects were studied. Ex-Post facto research design was employed in the study. Percentages of students who obtained grade 1 - 6 in the 5 subjects were used to analyse the data. It was found that there was steady increase in the enrolment of students in the 5 subjects however, with fluctuating performances in Biology, Chemistry, General Mathematics and English language, except Physics which recorded an increased performance that fluctuated only in 2009. In terms of average academic performance from $2008-2012$, physics recorded the best average academic performance with mean of $56.01 \%$ followed by English $(52.52 \%)$, Mathematics (47.44\%), Chemistry $(46.30 \%)$ and the least average academic performance was in biology (37.27\%). It was also found that Biology had the highest failure rate of $28.66 \%$ followed by Mathematics (24.39\%), Chemistry (22.52\%), English $(21.89 \%)$ and the least failure rate was in physics $(13.08 \%)$. The results also show that from $2008-2012$ only $46.50 \%$ of the students obtained $1-6$ grades in Biology, Chemistry, Physics, Mathematics and English in WASSCE. The implication of these abysmal performances is that the pace of achieving national development and the MDGs will be slow and difficult. It was recommended that there should be a total overhaul of the teaching and learning process of these subjects.
\end{abstract}

Keywords: Assessment, Students' performance, Science, Millennium Development Goals.

\section{INTRODUCTION}

Education is a critical component of human and national development. It is in realisation of this that nations are investing heavily in education in order to be part of the global quest for sustainable development. Despite the huge investments in education, the performance of students in Senior School Certificate Examinations (SSCE) has long been a matter of concern to many well-meaning individuals, institutions and organizations as well as to various levels of government (Kpolovie, Ololube, \& Ekwebelem. 2011).

Performance of students in the sciences has implications for the attainment of vision 20-2020 and the Millennium Development Goals (MDGs). Okeshola (2010) maintained that attaining the MDG's of eradicating poverty and hunger, promoting gender equality and the empowerment of 
women, reducing child mortality, improving maternal health, combating HIV/AIDS and ensuring environmental sustainability are predicated on sound education. Okeshola further posited that the acquisition and dissemination of the requisite knowledge and skills and their effective application to address challenges that cumulatively result in sustainable development are highly dependent on a strong education system. The development of any nation according to Olorundare (2011) is usually barometered by the degree and extent of socio-cultural, socioeconomic and political improvements that are brought to bear through the enterprise of science and technology.

In September 2000, the 189 member countries of the United Nations (UN), including 147 heads of states adopted the eight Millennium Development Goals (MDGs) committing themselves to making substantial progress towards eradication of extreme poverty, hunger and achieving other human developmental goals by the year 2015 (Abdulgafar, Ibrahim \& Alasinrin, 2013). They further stated that these goals are characterized with eighteen targets and 48 indicators. It is just a year left for the nations to attain the Millennium Development Goals; to what extent are these goals being achieved? This is the thrust of this paper, to assess the trend of secondary school students' academic performance in West African Senior School Certificate Examination (WASSCE) in Biology, Chemistry, Physics, Mathematics and English as these subjects are germane to the attainment of the Millennium Development Goals and vision 20-2020.

The use of examinations to carry out assessment according to Alonge (2003) has been on the increase worldwide with the establishment of examination bodies like: West African Examinations Council (WAEC, 1953), National Teachers Institute (NTI, 1975), National Board of Educational Measurement (NBEM, 1992), National Business and Technical Examination Board (NABTEB, 1992), National Board of Technical Education (NBTE, 1993) and National Examinations Council (NECO, 1998). These examination bodies were established to replace the activities of the colonial examination bodies.

WASSCE is a Senior School Certificate Examination (SSCE) conducted By West African Examination Council. The choice of WASSCE results was due to its credibility and acceptance by tertiary institutions for higher education. Kpolovie, Ololube, \& Ekwebelem. (2011) are of the view that because of the economic and social importance attached to senior secondary school certificates, and the opportunities for higher education for those who possess such certificates, the awarding of this certificate is one of the most important events in the Nigerian academic calendar.

The utter disregard for science and technology education as an instrument of development has caused incalculable damage to our corporate existence. The problems of mismanaged economy, mass unemployment, collapse of health and educational services, insecurity, inflation, collapsed infrastructure can all be traced to the inadequate attention paid to science and technology in Nigeria (Egbogah, 2012). Strides in science and technology were catalysts in the development of many countries in the world. The assessment of students' academic performance in Biology, Chemistry, Physics, Mathematics and English was because these subjects are the requirements for university admission in Nigeria for students who want to study medicine, engineering, pharmacy, Computer science and other science and technology related courses which are crucial for the attainment of the Millennium Development Goals.

\section{Statement of the Problem}

National and international goals can only be achieved through a well-planned curriculum (Nwakonobi \& Onwuachu, 2009). The Nigeria Education Research and Development Council (NERDC) in response to a directive from National Council on Education (NCE) in 2005 
developed a new Basic Education Curriculum in line with national and global reforms in education. In response to the on-going national and global reforms such as the Millennium Development Goals (MDGs) and to further consolidate the gains of the new Basic Education programme, it became imperative that the existing curriculum for senior secondary schools be reviewed and re-aligned to fit the reform programmes (Sakiyo \& Waziri, 2014).

However, recent developments has shown marginal decline in students' performance. Dike (2014) reported that only $31.28 \%$ of the students that sat for 2014 May/June WASSCE obtained five credits including English and Mathematics as compared to $38.81 \%$ in 2012 and $36.57 \%$ in 2013. With just a year to the end of the attainment of the MDGs; this study was designed to assessed students trend of academic performance in Biology, Chemistry, Physics, Mathematics and English in WASSCE from 2008 - 2012. This is because students' academic performance in these 5 subjects would determine the production of scientific literate citizens and future scientist and technologists desperately needed for national development and attainment of international reforms such as the MDGs.

\section{METHODOLOGY}

The study adopted an Ex-Post facto design to assess the trend of students' academic performance in West African Senior School Certificate Examination (WASSCE) in Biology, Chemistry, Physics, Mathematics and English from 2008 - 2012 in Nigeria. In Ex-Post facto studies, variables are studied in retrospect in search of possible relationships and effects. The population of the study consisted of all the students that sat for WASSCE in the 5 subjects under study from 2008 - 2012. There was no sampling as the entire population was studied. Documentary evidence (data) from West African Examination Council (WAEC) was used in the study.

\section{Research Questions}

The following research questions guided the study.

1. What is the trend of the number of secondary school students who sat for WASSCE in Biology, Chemistry, Physics, Mathematics and English from 2008 - 2012?

2. What is the trend of the performance of secondary school students who passed WASSCE with grade 1 - 6 in Biology, Chemistry, Physics, Mathematics and English from 2008 2012?

3. What is the average academic performance of secondary school students per subject who passed WASSCE with grade 1 - 6 in Biology, Chemistry, Physics, Mathematics and English from 2008 - 2012?

4. What is the failure rate of secondary school students in WASSCE in Biology, Chemistry, Physics, Mathematics and English from 2010 - 2012?

5. What is the overall average academic performance of secondary school students who passed WASSCE with grade 1 - 6 in Biology, Chemistry, Physics, Mathematics and English from 2008 - 2012?

\section{Presentation of Results}

Data was analysed based on the research questions.

Research Question 1: What is the trend of the number of secondary school students who sat for WASSCE in Biology, Chemistry, Physics, Mathematics and English from 2008 - 2012 ?

Table 1 was used to answer research question $1-3$ and 5. 
Table 1: Number and Percentages of Students who obtained Grades 1- 6 in WASSCE in Biology, Chemistry, Physics, Mathematics and English from 2008 - 2012

\begin{tabular}{|c|c|c|c|c|c|c|}
\hline Subject & 2008 & 2009 & 2010 & 2011 & 2012 & Average \\
\hline $\begin{array}{c}\text { Biology } N . \\
\%\end{array}$ & $\begin{array}{c}1259965 \\
33.94\end{array}$ & $\begin{array}{c}1340206 \\
28.95\end{array}$ & $\begin{array}{c}130048 \\
49.65\end{array}$ & $\begin{array}{c}1505199 \\
38.50\end{array}$ & $\begin{array}{c}1646150 \\
35.66\end{array}$ & 37.27 \\
\hline $\begin{array}{c}\text { Chemistry N. } \\
\%\end{array}$ & $\begin{array}{c}418423 \\
44.44 \\
\end{array}$ & $\begin{array}{c}468546 \\
43.69 \\
\end{array}$ & $\begin{array}{c}465643 \\
50.70 \\
\end{array}$ & $\begin{array}{c}565692 \\
49.54 \\
\end{array}$ & $\begin{array}{c}627302 \\
43.13 \\
\end{array}$ & 46.30 \\
\hline $\begin{array}{c}\text { Physics N. } \\
\%\end{array}$ & $\begin{array}{c}415113 \\
48.26\end{array}$ & $\begin{array}{c}465636 \\
47.83\end{array}$ & $\begin{array}{c}463753 \\
51.27\end{array}$ & $\begin{array}{c}563161 \\
63.94\end{array}$ & $\begin{array}{c}624658 \\
68.74\end{array}$ & 56.01 \\
\hline $\begin{array}{c}\text { Mathemetics } \\
\mathrm{N} . \\
\%\end{array}$ & $\begin{array}{c}1268213 \\
57.27\end{array}$ & $\begin{array}{c}1348528 \\
47.04\end{array}$ & $\begin{array}{c}1306535 \\
41.95\end{array}$ & $\begin{array}{c}1508965 \\
40.35\end{array}$ & $\begin{array}{c}1658357 \\
50.58\end{array}$ & 47.44 \\
\hline $\begin{array}{c}\text { English N. } \\
\%\end{array}$ & $\begin{array}{c}1274166 \\
35.02\end{array}$ & $\begin{array}{c}1355725 \\
41.55\end{array}$ & $\begin{array}{c}1307745 \\
35.13\end{array}$ & $\begin{array}{c}1514164 \\
57.25\end{array}$ & $\begin{array}{c}1658887 \\
58.51\end{array}$ & 45.50 \\
\hline Average \% & 43.79 & 41.74 & 45.74 & 49.92 & 51.32 & 46.50 \\
\hline
\end{tabular}

Source: WAEC, 2012

\section{KEY}

N. = Number of students that sat for the subject

$\%=$ Percentage of students that passed with grade $1-6$ in the subject

Table 1 showed a steady increase in the number of students who sat for WASSCE from 2008 2012. The highest increase was in Mathematics from 1, 268, 213 to 1, 658, $357(390,148)$ it was followed by Biology from 1, 259, 965 to 1, 646, $150(386,185)$ candidates, then English from $1,274,166$ to $1,658,887(384,721)$ candidates, which was also followed by Physics from 415,113 to $624,658(209,545)$ and Chemistry 418,423 to $627,302(208,879)$ candidates.

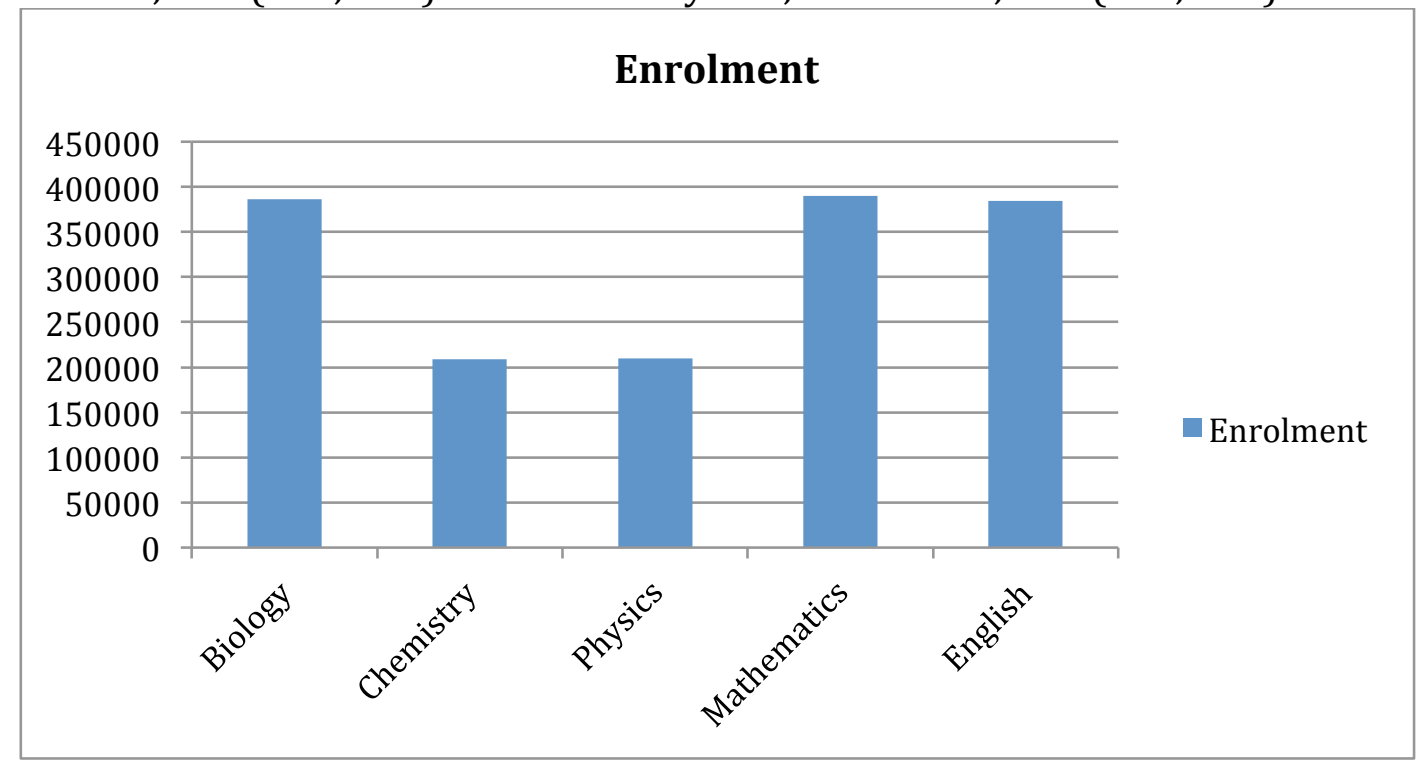

Figure 1: Bar-Chart of trend of increase in the number of secondary school students who sat for WASSCE in Biology, Chemistry, Physics, Mathematics and English from 2008 - 2012

Research Question 2: What is the trend of performance of secondary school students who passed WASSCE with grade 1 - 6 in Biology, Chemistry, Physics, Mathematics and English from $2008-2012$ ?

Result from table 1 indicated a fluctuating performance in all the subjects except that physics recorded a steady increase in students' academic performance and fluctuated only in 2009 (see Figure 1). 


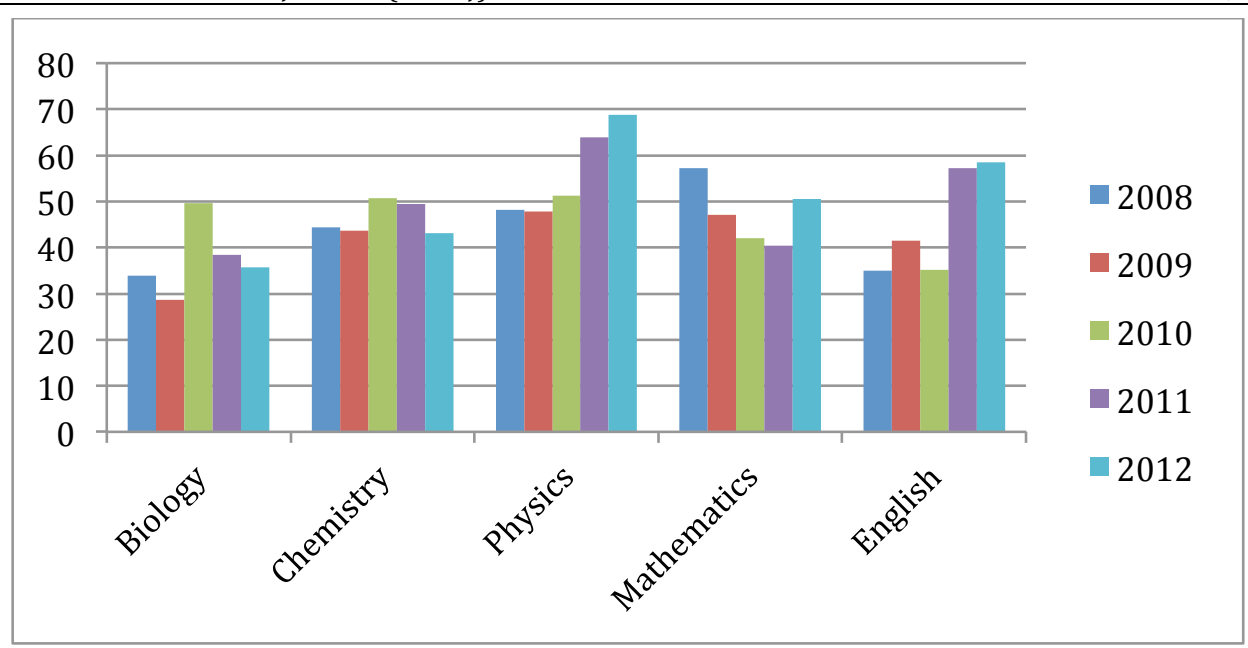

Figure 2: Bar-Chart of percentages of secondary school students who obtained $1-6$ grade in WASSCE in Biology, Chemistry, Physics, Mathematics and English from 2008 - 2012

Research Question 3: What is the average academic performance of secondary school students per subject who passed WASSCE with grade 1 - 6 in Biology Chemistry, Physics, Mathematics and English from 2008 - 2012?

Table 1 also revealed that Physics recorded the best academic performance with mean average of 56.01\% followed by English with 52.52\%, Mathematics 47.44\%, Chemistry $46.30 \%$ and the least academic performance was in Biology with $37.27 \%$.

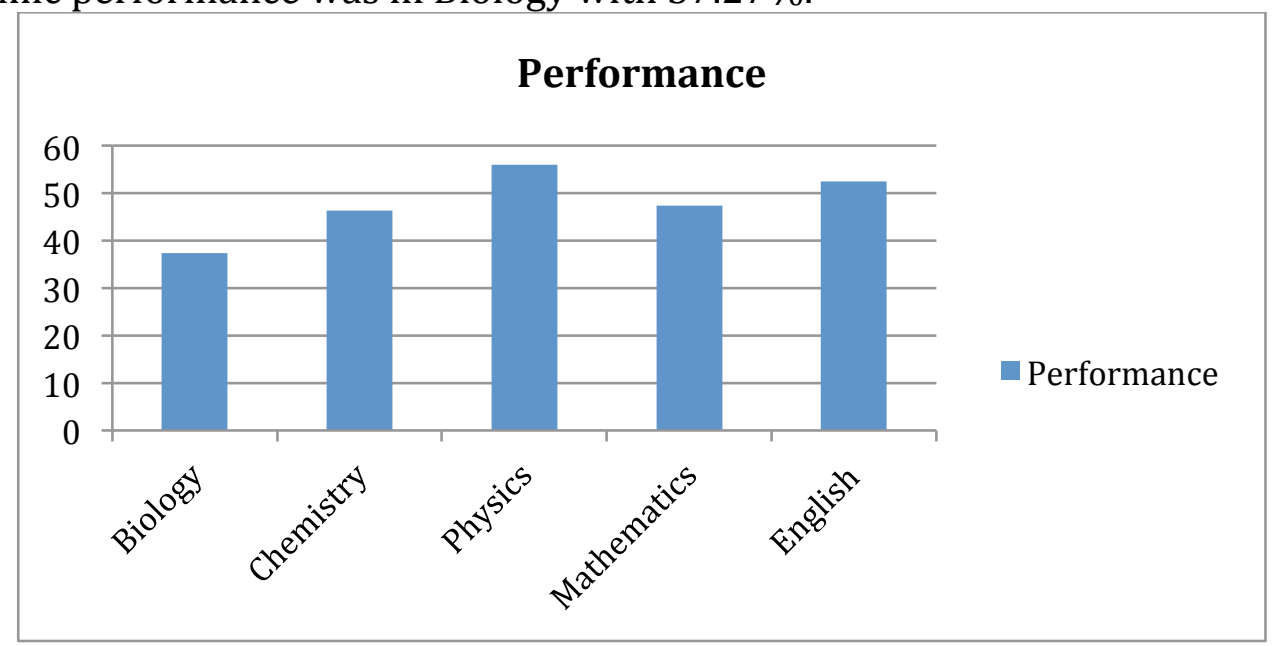

Figure 3: Bar-Chart showing the average academic performance of secondary school students who passed WASSCE with grade 1 - 6 in Biology Chemistry, Physics, Mathematics \& English from 2008 - 12

Research Question 4: What is the failure rate of secondary school students in WASSCE in Biology, Chemistry, Physics, Mathematics and English from 2010 - 2012? Table 2 is a presentation of the result to the question.

Table 2: Percentage of students failure rate in WASSCE from $2010-2012$

\begin{tabular}{|c|c|c|c|c|c|}
\hline Subject & 2010 & $\begin{array}{c}\text { \% of Failure } \\
2011\end{array}$ & 2012 & $\begin{array}{c}\text { Average } \% \\
\text { Failure }\end{array}$ & Rank \\
\hline Biology & 22.86 & 29.34 & 33.77 & 28.66 & 1 \\
\hline Mathemetics & 27.20 & 27.95 & 18.01 & 24.39 & 2 \\
\hline Chemistry & 21.08 & 22.82 & 23.65 & 22.52 & 3 \\
\hline English & 31.02 & 18.22 & 16.44 & 21.89 & 4 \\
\hline Physics & 18.27 & 11.76 & 09.20 & 13.08 & 5 \\
\hline
\end{tabular}

Source: WAEC, 2012 


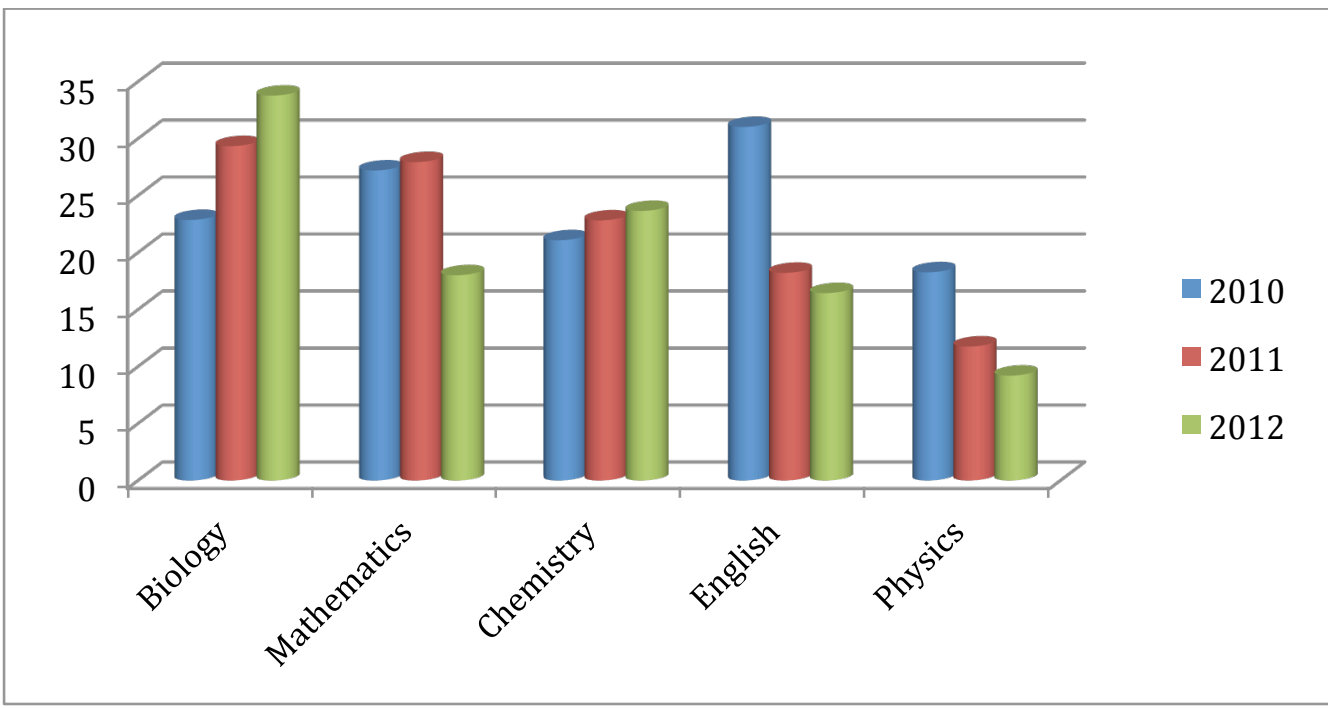

Figure 4: Bar-Chart of the failure rate of secondary school students in WASSCE in Biology, Chemistry, Physics, Mathematics and English from 2010 - 2012

The trend of failure rate was decreasing in Physics, English and Mathematics, while an increase in failure rate was recorded for Biology and Chemistry. The highest failure rate of $28.66 \%$ was recorded for Biology followed by Mathematics (24.39), Chemistry (22.52), English (21.89) and the least failure rate was in Physics (13.08).

Research Question 5: What is the overall average academic performance of secondary school students who passed WASSCE with grade 1 - 6 in Biology, Chemistry, Physics, Mathematics and English from 2008 - 2012?

The overall average academic performance of students in Biology, Chemistry, Physics, Mathematics and English from 2008 - 2012 is 46.50\% (see Table 1). This is a below average performance and should be of great concern to educationists and other Nigerians.

\section{DISCUSSION}

The study found a steady increase in the enrolment of students who sat for May/June WASSCE in Biology Chemistry, Physics, Mathematics and English from 2008 - 2012 in Nigeria without a steady increase in the students' academic achievement. These findings are consistent with Alaka and Obadara (2013) who reported poor students' academic performance in all geopolitical zones of Nigeria. The increase in enrolment may be attributed to expansion of secondary schools and increased access to school due to Universal Basic Education (UBE) and Education for all Programmes in Nigeria.

The study showed that the best performance of the students was in Physics while the lowest performance was in Biology. This corroborates Ibe and Maduabum (2001) report that candidates performance at the Senior School Certificate Examinations (SSCE) conducted by West African Examination Council have consistently remain poor, with biology having the highest enrolments and the poorest results over the years.

\section{Implications for the Attainment of the Millennium Development Goals}

Education is crucial in liberating man from ignorance and the attainment of any vision or goal. Science and technology is the engine room that drives technological development and invariably national development. The abysmal performance of students in science portends danger for the development of Nigeria and the attainment of international reforms such as the Millennium Development Goals. Similarly, poor performance of students in science implies that 
less students will pursue higher education in science and science related disciplines and careers.

\section{CONCLUSION}

The below average performance of students in Biology, chemistry, Physics, Mathematics and English from 2008 to 2012 in Nigeria, suggests that the attainment of the millennium Development Goals by 2015 may be difficult and impossible. Nigeria needs scientists and technologists to grease its wheel of development in science and technology which is an index of the developed nations of the world.

\section{Recommendations}

To salvage the dwindling performance of students in Biology, Chemistry, Physics, Mathematics and English in Nigeria, the government should put in place right policies, infrastructure and manpower in order to improve the teaching and learning process. Similarly, new developments and skills currently in use in the field of teaching and learning to secondary school students should be implemented in order to improve the quality of teaching strategies of the teachers as well as improve the learning processes of the students.

\section{References}

Abdulgafar, d. S., ibrahim, w, alasinrin, k. A. (2013). The extent of achieving the millennium development goals: evidence from nigeria kuwait chapter of arabian journal of business and management review 2 (9) 59 - 71

Alaka, a. A., obadara, o. E. (2013). Scholastic performance of students at west african senior secondary certificate examinations in nigeria. Journal of educational and social research 3 (1) 275 - 285

Alonge, m. F. (2003). Assessment and examination: the pathways to educational development. University of ado ekiti inaugural lecture series

Dikeh, g. (august, 2014). Waec records mass failure of candidates. The sun newspapers of 12th august, 2014. Retrieved from www.sunnewsonline.com/news/?p=76447 on 13th august 2014

Egbogah, e, o. (2012). The role of science and technology in national development: the miracle of malaysia and the future for nigeria. Petroleum technology development journal (1) 1 - 43

Ibe, b.o., and maduabum, m.a. (2001) teachers qualification and experience as correlates of secondary school students' achievement in biology. Journal of education thought, 1 (2) 176-183.

Kpolovie, p. J., ololube, n. P. \& ekwebelem, a. B. I. (2011). Appraising the performance of secondary school students on the waec and neco ssce from 2004 to 2006. International journal of scientific research in education, 4(2), 105114.

Nwakonobi, f. E., onwuachu, w. C. (2009). Sex education, a way forward towards biology curriculum delivery in secondary schools in anambra state. African research review, an international journal multi-disciplinary journal of ethiopia 3(2) 224-233

Okeshola, b. F. (2010). Challenges facing the realization of millennium development goals (mdg`s) in educational reforms in nigeria. European scientific journal february 8(3) 201-209

Olorundare, a. S. (2011). Correlates of poor academic performance of secondary students' in the sciences in nigeria. Paper presented at virginia state university, petersburg, virginia usa

Sakiyo, j. Waziri, k. (2014). Comparative study of old and new senior secondary school biology curriculum: a panacea for global reform programmes. Tsu journal of education research and production 3(2). Retrieved online from tsuerjournal.com/index.php/./12 on 12th june 2014

Waec. (2012). Year 2012 21nd waec state committee meeting agenda papers for taraba state. West africa examination council. 